\title{
Translating Patterns of Style in 'Hour of the Wolves'
}

\begin{abstract}
For a translator of poetry, it is important to analyse the style of the original poem in order to gain access to the poetics from which the poem arose. I consider here the translation of a German poem, 'Stunde der Wölfe', by Volker von Törne, into English. Stylistic patterns in the original poem include the central metaphor of wolves and many other metaphors: birds, paths and journeys, night and winter. There are images of curtailment, intervention and impediment caused by natural agents such as wolves, hawks, wind and snow. And there are several patterns of repeated sounds. The translator must also look beyond the poem itself, to the context in which the poet was writing, and to the use of metaphor and myth in both languages. Considering the interaction of all these elements allows the translator to find ways of translating that preserve the central images and stylistic patterns.
\end{abstract}

Keywords: style, poetics, translation, metaphor, context

\section{Prevajanje slogovnih vzorcev v »Uri volkov«}

\section{IZVLEČEK}

Za prevajalca poezije je pomembno, da analizira slog izvirne pesmi in na ta način pridobi vpogled v poetiko, v okviru katere je pesem nastala. $V$ članku se osredotočam na angleški prevod nemške pesmi „Stunde der Wölfe“, pesnika Volkerja von Törna. Stilistične figure v izvirniku so osrednja metafora volkov in številne druge metafore: ptice, poti, popotovanja, noč in zima. Pojavljajo se podobe zastiranja, poseganja in oviranja iz narave, ki jih povzročajo volkovi, sokoli, veter in sneg. Prav tako se pojavlja več ponavljajočih se zvočnih vzorcev. Prevajalec mora poleg same pesmi upoštevati tudi kontekst, znotraj katerega je pesnik pisal, pa tudi rabo prispodob in mitov v obeh jezikih. Šele z upoštevanjem vsega naštetega lahko prevajalec $\mathrm{v}$ prevodu ustrezno ohrani osrednjo podobo in slogovne vzorce.

Ključne besede: slog, poezija, prevod, metafora, kontekst 


\section{Introduction}

When we translate poetry, it is particularly important to examine and analyse the stylistic structures and patterns of the source poem, so that they can be carried over into the translation and still be recognized there (see Berman 2012, 248-50; Boase-Beier 2020, 128-67). These structures and patterns will inevitably change in translation, but it is crucial that they should not disappear, because they arise from the poetics of the original poet. They play a central role in the reading of the translated poem, where they allow the new readers access to the poetics of the original poet, filtered through the words of the translator, and transformed by that translator's particular interpretation.

I understand "poetics" as the set of beliefs and attitudes held by a poet (or other writer) about the possible ways of expressing in words whatever she or he wishes to say. The poetics of a particular poet always relate to the poet's world view: poetic style is always "mind-style" (Fowler 1977, 103). That is, the patterns of style in the poem, including its metaphorical and other structures, result (intentionally or unintentionally) from patterns of thought. When a translator performs stylistic analysis of the original poem, this is a way of gaining insight into the poetics that informed the writing of the poem, in order to create the new poem from the same basis.

The poem I am considering here is Volker von Törne's 'Stunde der Wölfe', translated into English as 'Hour of the Wolves' (see Boase-Beier and Vivis 2017, 108-9). One of the advantages of discussing one's own translation is that it is possible (though only to some extent) to discuss the reasons for decisions taken, and to make clear the basis for both the analysis of the source text and the way the translated text has been constructed.

\section{Real and Metaphorical Wolves}

"Wolves" in this poem could be understood as the actual animal, of the family canis lupus, but the juxtaposition with "hour of" in the title suggests a metaphor, and indeed the wolf is a likely candidate for metaphorical use, given its importance in everyday idioms, such as "to throw to the wolves", "to keep the wolf from the door" or "to cry wolf", as well as in folk tales and popular stories such as 'Little Red Riding Hood', or Frederick Marryat's 1839 story The White Wolf of the Hartz Mountains (Marryat 2004), or Jack London's White Fang (London 2019). These examples are of expressions and stories familiar to English speakers, but they do not necessarily originate in English. Wolves are important creatures of myth and legend in many cultures, and idioms to do with wolves exist in many different languages (see Biedermann 1992, 387-89).

Metaphor is one of the central structuring elements of poems and other literary texts, but it does not merely work within the text. As many writers since Lakoff and Johnson (1980) have shown (see, e.g., Lakoff and Turner 1989; Kövecses 2002; 2005; Gola and Ervas 2016), metaphor is a basic structure of thought, and plays an important role in communication in both literary and non-literary contexts. In order to understand how it works in a particular poem, and how it can be translated, we first need to understand how it works outside the poem. The connotations of wolves in everyday language, in popular culture, in myth and 
legend, and the way images of wolves are used, all play a role in understanding what they stand for in von Törne's poem.

The poem follows here in my English translation (Boase-Beier and Vivis 2017, 9):

Hour

Of the wolves, and

The songs of the girls in

The village

Fell still

The flight

Of the dove cut

Across by the hawk, the

Swallows transported

The light

Voices

Like calls, from away

In the darkness, wind

Drove snow over

The path

Reading the first lines of the original poem - "Stunde / Der Wölfe / Die Lieder der Mädchen / Verstummten" - prior to translation, the translator asks: Why "Stunde der Wölfe"? What is the hour of the wolves? What are the wolves and what do they stand for?

Wolves have a long history of interaction with humans; indeed, there has been interaction between humans and wolves, as far as we know, ever since wolves first existed in their modern form, around 40,000 years ago. Some wolves gradually became domesticated from at least 15,000 years ago to form, eventually, the many types of domestic dog, also canis lupus in most taxonomies (see Pierotti and Fogg 2017, 7, 24-26). Like most animals, wolves have contradictory associations in human culture. In Scandinavian and German myth, wolves are the creatures that witches ride on. In Jewish and Christian myth, in particular, they often represent evil, from which shepherds protect their real and metaphorical flocks. They can be nurturing animals, as in the legend of Romulus and Remus, who founded Rome, and they are often seen as fearless, or even sacred (for example, in Japanese and Ainu myth; see Walker 2008, 7-9). They are revered in the origin myths of Turkish and Mongolian cultures (see Findley 2005, 38-39). In spite of these contradictory connotations, wolves are, in Western tradition, usually symbols of destruction and danger, and they are familiar figures of fear in many children's stories, such as the Grimms' Fairy Tales, European traditional stories, including 'Little Red Riding Hood', collected by the Brothers Grimm and first published in German in 1812 (see Brothers Grimm 2011). 
While all these associations formed part of the background against which Volker von Törne wrote 'Stunde der Wölfe', there are more specific cultural elements relevant to the time and place of writing that also form part of the context of the poem, and need to be taken into account in its translation.

Von Törne wrote this poem in the late 1970s; it appeared in his collection 'Kopfüberhals' (literally "head over neck"; an inversion of a common German idiom usually rendered in English as "head over heels") in 1979 (see von Törne 1981). Von Törne was the son of a unit commander in the SS (Schutzstaffel, literally "protection squadron", the Nazi paramilitary organization) and had been exposed to German Nazism as a small child in the late 1930s. When the war ended in 1945, von Törne, then eleven years old, gradually became aware of the evils of Nazism and the collective guilt of the German people. Determined, as he grew up, that people must not forget what had happened, he became an early member, and later a director, of the Christian left-wing organization Aktion Sühnezeichen Friedensdienste (Action Reconciliation - Service for Peace) that pledged to make reparation wherever possible for the war and oppression that had started in Germany.

Much of his poetry expresses his personal feelings of guilt as well as the guilt that he felt all Germans should take upon themselves after the Holocaust, and there is often a strong sense of the need to understand that we cannot simply go back to a time of innocence, however much we might wish to. For von Törne, the innocence of his childhood was always tainted in retrospect with his later knowledge of what had actually been happening when he was a child. His poems often juxtapose a longing for innocence with a sense that it is never possible to regain it.

The poem 'Hour of the Wolves' is thus also to be seen in the context of the aftermath of the Second World War in Germany, a catastrophe that profoundly affected the post-war generation, guilty only by association, to which von Törne belonged.

The wolf metaphor was in fact common in the mythology that the Nazis had tried to create about themselves. Hitler's military headquarters in what is now North Poland, in the Masurian Woods, an area von Törne knew well, and that features in several of his poems, was called "Wolfsschanze" (wolf's lair); other headquarters in Belgium were called "Wolfsschlucht" (wolf's gorge); the plan to create a resistance force was referred to as "Operation Werewolf", and Hitler liked to point out that his name, Adolf, came from "edel" (noble) and "Wolf". The connotations the Nazis hoped to evoke were those of strength and a warrior-like character. The wolf's more negative connotations, often perhaps in allusion to the Nazis' own use of the metaphor, are sometimes used in Holocaust literature; for example, Nackt unter Wölfen (Naked Among Wolves) is the title of a well-known novel of 1958 by Bruno Apitz, set in the Buchenwald concentration camp where Apitz had been imprisoned.

Von Törne was very influenced as a poet by Bertolt Brecht, and especially by the latter's use of everyday language, idiom and metaphor. Brecht used the image of the wolf a great deal, almost always with negative connotations (see Mennemeier 1982, 91-105). Wolfspelz (wolfskin; an inversion of "a wolf in sheep's clothing") was an earlier collection of von Törne's poetry (see von Törne 1981). In giving a poem the title 'Hour of the Wolves', von Törne is 
therefore situating it within a broad set of cultural and literary connotations of wolves as well as in the more specific context of the Holocaust and Holocaust writing. The phrase "hour of the wolves" also has a very exact metaphorical meaning, that relates to the well-known expression "entre chien et loup" in French: the twilight hour, the hour between the domestic and the wild, between the light of day and the darkness of night.

This is a poem that thus suggests something happening at (real or metaphorical) twilight. The poem describes a time in a village, imagined or real, at which songs go quiet, the light disappears, voices can be heard in the distance, the path - perhaps the way forward or back to the village - is blocked by snow.

\section{Patterns of Style and their Translation}

The stylistic elements of a poem always work together in the text, as their cognitive counterparts worked together to shape the poetics that formed the basis from which the poem was written. The metaphor of the wolf, with all the connotations it draws from usage in everyday idiom, in legend, and in the specific context of the Holocaust, is thus part of a network of stylistic features, all of great concern to the translator.

A translator can identify three strands of the network in the original poem of which the translation is given above:

(i) a set of animal metaphors

(ii) a series of interventions and impediments

(iii) a number of patterns of sound

Analysing these strands, each of which represents a stylistic pattern, and considering the way the wolf metaphor fits into each one, helps determine how the poem can be translated into English and what adjustments have to be made so that the whole stylistic network can be preserved.

With respect to (i), we note that idioms are not merely haphazard figures of language. They are "products of our conceptual system" (Kövecses 2002, 201), and are often based upon conceptual metaphors, that is, metaphors that form part of our cognitive make-up, and that structure the way we think by bringing together two domains of knowledge. Thus, argument is often associated with war or death with night. Conceptual metaphors are usually written in capitals: ARGUMENT IS WAR; DEATH IS NIGHT.

Many conceptual metaphors occur across a number of different cultures, though others appear to be culture-specific (Kövecses 2005, 2-5). Idioms and stories in both English and German indicate that the two languages and cultures share many conceptual metaphors that give rise to expressions relating to wolves as representing danger. The image of the "hour of the wolves", though there is not in fact an idiom in German or English comparable to "entre chien et loup", is in both languages easily interpretable as an hour at which the darkness approaches and danger comes, with a loosening of the ties of the domestic. The songs of the 
girls "verstummten": they became dumb, or fell silent. This suggests a sudden cessation of sound caused by outside intervention, rather than a decision to stop singing.

The wolf metaphor is part of a series of animal metaphors in the poem. Goatly $(2007,125-32)$ maintains that expressions comparing humans to animals are generally negative. In part this is because they reduce the complexities of humanity to the level of other animals, suggesting a lack of the emotions we attribute to humans. Kövecses $(2002,124-25)$ says that such metaphorical uses are instances of a broader conceptual metaphor, PEOPLE ARE ANIMALS, and are negative because they relate to the "Great chain of being", a view of the world in classical and mediaeval thought that put God at the top of the chain, followed by angels, then humans, and with animals below (see Lakoff and Turner 1989, 166-69; Musolff 2010, 16).

In this poem, all the other animal metaphors take birds as their source domain. The three bird metaphors in the second stanza are again common to both German and English: "doves and hawks" is a commonly-used metaphor in both languages that refers to peace-makers and aggressors, in a military, political or economic context. Swallows are often used to suggest the air and the light, or the coming of spring: one swallow does not make a summer in English, as in German; this is a very old proverb that possibly derives from Ancient Greek (Biedermann 1966, 332). Swallows also symbolize repentance, life after death, and heaven (Biedermann 1966, 332-33). Birds are frequent symbolic elements in von Törne's poems, where they generally carry their common connotations: crows symbolize oracles and portents, doves peace and love, eagles victory and renewal, vultures death. The dove is also a Christian symbol of the Holy Spirit, and in another poem, 'On Paths of Ashes', von Törne specifically rejects any suggestion of Christ-like status by stating that "There was no dove descending to rest upon me" (Boase-Beier and Vivis 2017, 57)

From the point of view of translation from German into English, these animal metaphors taken in isolation would appear not to pose particular problems, because their usage is common to both languages, and von Törne does not generally invest animal metaphors with any particular personal meaning. However, they cannot be taken in isolation: the metaphor of the wolves, like those of the birds, is part of another stylistic pattern: that of a set of interventions that occur throughout the poem; this is point (ii) in the list of stylistic patterns given above. The hour of the wolves causes the songs of the girls to fall still. The reader is likely to interpret this as some danger which enters the village and silences the girls. Similarly, the dove's flight, which suggests peaceful progression, is bisected by the hawk, that is, an aggressive presence cuts across it. Swallows, instead of bringing light and hope, carry it away. Swallows fly off just before dark and leave European countries just before winter, so dark and winter are both expected, and indeed both have come by the final stanza, when snow blows across the path, presumably cutting it off. Both dark and snow are common images in poems of the Holocaust (see Boase-Beier 2017, 156), where they often suggest death, and also attempts to cover up killing. The conceptual metaphor DEATH IS NIGHT, mentioned above, is discussed by many writers on metaphor (e.g., Lakoff and Johnson 1989, 8; Kövecses 2002, 44). Snow can suggest death because snow comes in winter and DEATH IS WINTER is also a conceptual metaphor, related to the broader metaphor A LIFETIME IS A YEAR (Lakoff and Turner 1989, 18, 28), just as DEATH IS NIGHT is related to A LIFETIME 
IS A DAY (Lakoff and Turner 1989, 28). The cutting-off movements described in the poem thus themselves relate to a set of metaphors of life and death.

The metaphor of the wolf, then, is both an element in the pattern of animal metaphors and also an element in a broader pattern of metaphorical natural agents (wolves, hawk, swallows, darkness, wind, snow) that interrupt or end the normal processes of life. It is when we understand these common metaphors - of animals and other natural phenomena - in the context of their interventions in the movements described in the poem that we are able to access further possible meanings, and to see greater consequences for translation. If metaphors, especially those that arise from common conceptual metaphors, translate easily, particularly between languages like German and English with similar mythological and cultural traditions, this is not true of described movement, which is often echoed in syntax. The syntax of English is very different from the syntax of German.

In order to process the series of movements occurring in the poem the reader needs to take a perspective. This is likely to be that of the narrator, but there is only one clue to the narrator's position in the English version given above, and that is the expression "from away" in the third stanza. The German has "fern" (far) here, and also has "fort" (away) in the second stanza: "fort trugen/Die Schwalben/Das Licht" (the swallows transported the light). However, "fort" is not a free-standing adverb here but the separated prefix of the verb "forttragen" (to carry off) and, as part of the verb, is deictically weak, in that it does not necessarily denote a movement away from the narrator's position, though it implies it, as does "transported". "From away" in the third stanza is deictically much clearer: it indicates that the sound is being produced at a distance from where the narrator is located. Beyond these two expressions, the narrator's presence is implied only by the fact that someone must hear the sudden silencing of the songs at the end of the first stanza, and interpret the voices as "like calls" in the final stanza. The reader is likely to take the perspective of someone standing fairly near to the village at the start of the poem (close enough to hear songs cut off), and being further away at the end.

The narrator in this final stanza hears "Stimmen wie Rufe", that is, voices that sound like calls. "Ruf", like the word "call" in English, is also used of the sound made by a bird. The voices heard in the last stanza are ambiguous. They might be the calls of the birds: either of the hawks, which suggest the aggressors, or of the doves, which suggest the victims, the girls. They might be the latter's calls for help. Seen from the narrator's perspective, it is actually the movement of the sound of the girls' voices to reach the listening narrator's ears that is cut off. The interpretation of sounds as calls also suggests a call to action such as that felt very strongly by von Törne throughout his life, a call to atone for wrongs. At the end of the poem it seems that the position of the speaker is now beyond the village, and that it is not possible to return because the path is blocked by snow. The picture becomes clearer when we see that the snow is performing the same action as the wolves, the hawk, the swallows and the wind: it is cutting sideways across an imagined trajectory.

The sense of movement in the poem is related to another conceptual metaphor, LIFE IS A JOURNEY (Lakoff and Turner 1989, 3-4; Kövecses 2002, 70-71). Lakoff and Turner (1989, 3-4) discuss how we understand this metaphor in Robert Frost's poem 'The Road Not Taken' (Frost 2018, 132) where we see the roads as ways to live one's life. It is similar here: the 
narrator is a traveller (as von Törne was), difficulties and dangers are natural agents (wolves, hawk, swallows, darkness, wind and snow), and so on. Kövecses follows Lakoff and Turner in assuming that LIFE IS A JOURNEY is a "special case of the more general metaphor PURPOSES ARE DESTINATIONS" (Kövecses 2002, 70), and in this sense the place von Törne was aiming for in his travels was, like the path the narrator follows, somewhere where we will all have learned from the past. This is not to say that the narrator in the poem is von Törne. It is, however, important to recognize that it is von Törne's poetics that inform the poem. Personal history, as Kövecses $(2005,242)$ has noted, affects the source domains we choose for our metaphors, and von Törne, in choosing to write of wolves, darkness, hawks and doves, snow, and a blocked path, was both reflecting other Holocaust poetry and no doubt also using his own experiences of childhood innocence, of his holidays in the Masurian Woods, where real wolves have never been extinct and metaphorical wolves lurked between 1941 and 1944, as he later came to realise. If the journey the narrator undertakes and the reader imagines is on a path cut off by wind and snow, this suggests either a difficult journey to a future that acknowledges the guilt of the past, or an inability to return in imagination to the source of the danger: the attack of wolves that cut off the voices in the village, causing them now to sound like calls.

The metaphor of movement along a path, especially movement that is impeded, is not an isolated interpretation that is only relevant to this poem. Many of von Törne's poems such as 'Leaving', 'Paths' or 'On Paths of Ashes' (Boase-Beier and Vivis 2017, 27, 29, 57-59) are about journeys, and this is not surprising, given the many journeys and lecture-tours he took part in, in order to try and atone for what his country, and specifically his own father, had done. That he never felt fully able to atone was one source of his guilt.

The syntax in the German poem signals the movement of outside agents acting upon the narrator's trajectory, and this is most obvious in the curious structure of the second stanza. The first half of the stanza is the phrase: "Den Flug der Taube kreuzte der Habicht", literally "the flight of the dove (object) crossed the hawk (subject)", that is, the hawk crossed the dove's flight. While it is perfectly possible in German to begin a sentence with the object, here "the flight" (den Flug), the effect of doing this is to foreground the dove's flight, and its interruption, thus making it parallel with the girls' songs in the first stanza. English cannot easily put the object first in active constructions, so the English translation of the phrase, in order to foreground the dove's flight, has to be in the passive. To avoid introducing too many words (e.g., "was cut across") and thereby losing the tightness of the rhythm, the English translation can easily omit the auxiliary: "The flight of the dove cut across by the hawk". "Cut across" is used for "kreuzte" (crossed) because it emphasizes the interruption to the movement, which might otherwise be less obvious in the more standard syntax of the English version. The word "kreuzte" in the German poem, a verb derived from the noun "Kreuz" (cross), just as in English "to cross" is derived from the corresponding noun, has many connotations. In Middle High German it meant "to crucify". Whether or not this fact is known to a German reader of the original poem, the connotations of peace falling victim to aggression are still present. A cross in both German and English is a symbol of intersecting paths, and it plays a part in many religions apart from its specific significance in Christianity as a symbol of the Crucifixion of Christ. The hook-cross (Hakenkreuz) or swastika was adopted by the Nazis 
from an ancient symbol found in many cultures that represented a moving or turning cross. The use of "kreuzte" thus more specifically suggests the Nazi misappropriation of a sacred symbol, that led to its being associated with hawks rather than with doves. To "cross" in English is both to cut across a path or trajectory in a movement from the side, and also to frustrate someone in their attempt to do something, or, as "cross out", to erase or invalidate something. Though the structures differ slightly in the two languages, the connotations are similar, as is the image the verb gives rise to in the reader's mind. The second meaning, to invalidate or frustrate an action, is especially evident in the final stanza, where this verb is not present, but the movement is the same.

The final point noted above, (iii), the series of sound-patterns, is of particular concern to the translator aiming to preserve the way different stylistic patterns interact. The most striking figure of sound in the German poem is the regular rhythm, with its connotations of song, which relies on a series of two-syllable words, such as "Stunde", "Wölfe", "Mädchen", whose obvious equivalents - hours, wolves, girls - are monosyllabic in English. Monosyllabic words in the German original, such as "Flug", "Licht", "Weg", are supplemented by definite articles so that "der Flug" (the flight), "das Licht" (the light) and "den Weg" (the path), for example, can easily fit the pattern. The problem with English is that the definite article cannot change form to indicate case or gender. Instead of "der", "das", "den" in the above noun phrases we would always have "the". This would make the translation clumsily repetitive and would thereby distract from the patterns of repetition that do seem central to the poem. So the translator needs to find a way to introduce variation, and this is done in the translation here by moving the articles to different positions in the line. The effect is different from the German, which begins each line in the second stanza with a different form of "der", but it avoids the pointless foregrounding of the article. It also allows the addition of extra syllables where needed to keep the rhythm regular.

Another pattern of repetition is in the etymologically related words "Stimme" (voice) and "verstummten" (fell silent), which, in their similarity of form, are echoed in other words of different origin - "Stunde" (hour), "Schwalben" (swallows), "Schnee" (snow) - to give an alliterative pattern. There is assonance in "Schnee - wehte - Weg" (snow - blew - path) in the third stanza and further alliteration in "wehte - Wind - Weg" (blew - wind - path) in the same stanza.

As indicated by the rough equivalents just given, these sound patterns are not easily echoed in English, yet they are important. In a poem of only thirty-six words in German, twenty-six have already been identified in this brief discussion as forming part of central metaphorical or phonological patterns, and they give a striking density and intensity to the short poem, making it seem as much about repetitive thought as about a journey, and thus linking repetitive thought and memory with the image of a journey that cannot be retraced. That is, the repeated sounds can be seen as instances of iconicity (see Fischer and Nänny 1999). When patterns of style are understood as iconic in that they suggest in their form a specific meaning that the words alone do not convey, they need to be treated with particular care by the translator (Boase-Beier 2020, 119-24). The dense repetition in rhythm, assonance and alliteration in this poem is likely to be understood by the translator as suggestive of 
repeated thoughts, of memory, and also of guilt. So it is not so much that the translator needs to compensate for the possible loss of sound patterns - as though they were mere poetic embellishment - as that the poem needs to achieve a similar stylistic density, and the sound patterns a similar ability to be read as iconic. The English translation uses assonance and alliteration where it occurs naturally: "village - fell - still - call", "flight - light", "drove snow - over". One could object that the patterns are different, since the German alliteration and assonance patterns more clearly underline the linking of voice with silence and the agency of nature. But such interpretations are not fixed in either language, and it is up to the translator to decide to what extent a particular interpretation is justified on the basis of von Törne's other work, and the stylistic evidence. For any interpretation, however, the density of stylistic patterns will be important, because it is so striking in the original.

\section{Conclusion}

Important as the various stylistic patterns in the poem are in order to get a sense of its poetics, and in order to write the translation on the basis of its reconstructed poetics, a poem is also about something. That is, it is not only a network of interacting stylistic patterns. The poem discussed here is, in a very fundamental sense, about wolves. Its title uses the connotations of wolves and their place in stories, legends, idioms, symbols, and recent history, in order to set a somewhat sinister tone, and the poem goes on to echo the imagined actions of wolves in those of other natural agents as day turns to night and winter comes.

The stylistic patterns I have described as structuring the original poem, and also the translation, begin with the wolves, and lead to other animal metaphors. The actions of wolves lead also to metaphors of journeys, paths, and progress cut off, underlined by the syntactic patterns of the German poem. Repeated sounds that suggest the repetitive thought of memory further interact with the various metaphors and with the images of natural agents that act as impediments to the path the narrator appears to be following.

Many elements of the stylistic analysis of the source poem rely upon the research undertaken by the translator. Here, that research involved examining and understanding the geographical, historical and literary situation in which von Törne was writing, discovering how he used metaphors, and how his use differs from other uses of similar metaphors, and to what extent conceptual metaphors might differ across cultures. It involved research into zoological, cultural, literary and mythological aspects of wolves, since they appear to be a central metaphor.

On the basis of such research and analysis it is possible to give solid evidence for many aspects of the translator's interpretation of the original poem. But it remains an interpretation, with which the resulting translated poem will be consistent.

There are many other points in the translation besides those discussed here that I could give as instances where I have attempted to ensure a pattern is kept, a movement or intervention reflected, a conceptual metaphor brought into the English text. But a translation is more than an attempt to recreate patterns, or to compensate for them where English does not readily comply. It is much more the case that all the patterns in the original, including the 
metaphors, movements and sounds discussed here, together create a sense of a complex poetics. The translation is written out of an idea of how this poetics, von Törne's poetics, with all its personal, historical, contextual and cognitive resonances, might have looked.

\section{References}

Apitz, Bruno. 1958. Nackt unter Wölfen. Halle: Mitteldeutscher Verlag.

Berman, Antoine. 2012. "Translation and the Trials of the Foreign." Translated by Lawrence Venuti. In The Translation Studies Reader. 3rd ed., edited by Lawrence Venuti, 240-53. London: Routledge.

Biedermann, Hans. 1992. The Wordsworth Dictionary of Symbolism. Translated by James Hulbert. Ware: Wordsworth Editions.

Boase-Beier, Jean. 2017. “Holocaust Poetry and Translation.” In Translating Holocaust Lives, edited by Jean Boase-Beier, Peter Davies, Andrea Hammel, and Marion Winters, 149-66. London: Bloomsbury.

-. 2020. Translation and Style. 2nd ed. London: Routledge.

Boase-Beier, Jean, and Anthony Vivis, trans. 2017. Volker von Törne: Memorial to the Future. Todmorden: Arc Publications.

Findley, Carter Vaughn. 2005. The Turks in World History. New York: Oxford University Press.

Fischer, Olga, and Max Nänny, eds. 1999. The Motivated Sign. Amsterdam: John Benjamins.

Fowler, Roger. 1977. Linguistics and the Novel. London: Methuen.

Frost, Robert. 2018. Selected Poems of Robert Frost. New York: Sterling.

Goatly, Andrew. 2007. Washing the Brain: Metaphor and Hidden Ideology. Amsterdam: John Benjamins.

Gola, Elisabetta, and Francesca Ervas. 2016. Metaphor and Communication. Amsterdam: John Benjamins.

Grimm, Brothers. 2011. Grimms' Fairy Tales. London: HarperCollins.

Kövecses, Zoltán. 2002. Metaphor: A Practical Introduction. Oxford: Oxford University Press.

-. 2005. Metaphor in Culture: Universality and Variation. Cambridge: Cambridge University Press.

Lakoff, George, and Mark Johnson. 1980. Metaphors We Live By. Chicago: Chicago University Press.

Lakoff, George, and Mark Turner. 1989. More Than Cool Reason: A Field Guide to Metaphor. Chicago:

University of Chicago Press.

London, Jack. 2019. The Call of the Wild, White Fang and Other Stories. New York: Penguin.

Marryat, Frederick. 2004. The White Wolf of the Hartz Mountains. Whitefish: Kessinger Publishing.

Mennemeier, Franz Norbert. 1982. Bertolt Brechts Lyrik. Düsseldorf: Bagel.

Musolff, Andreas. 2010. Metaphor, Nation and the Holocaust: The Concept of the Body Politic. Hoboken: Taylor and Francis.

Pierotti, Raymond, and Brandy Fogg. 2017. The First Domestication: How Wolves and Humans Coevolved. New Haven: Yale University Press.

von Törne, Volker. 1981. Im Lande Vogelfrei: Gesammelte Gedichte. Berlin: Verlag Klaus Wagenbach. Walker, Brett. 2008. The Lost Wolves of Japan. Seattle: University of Washington Press. 